Gut, 1975, 16, 331-336

\title{
The vagus, the duodenal brake, and gastric emptying
}

\author{
M. SHAHIDULLAH, T. L. KENNEDY, AND T. G. PARKS \\ From the Department of Surgery, Queen's University, and Royal Victoria Hospital, Belfast, N. Ireland
}

SUMMARY It has been suggested that an intact vagal supply is essential for the normal function of the receptors in the duodenum and proximal small bowel, which influence the rate of gastric emptying. This paper reports the effect of vagal denervation on gastric emptying and also examines the site and mode of action of receptors in the proximal small bowel.

It has been demonstrated in the dog that most, if not all, the receptors controlling gastric emptying lie in the proximal $50 \mathrm{~cm}$ of the small bowel. Following truncal vagotomy the emptying time of each instillation increased significantly and the differential rate of emptying of different instillations remained unchanged. The proximal $50 \mathrm{~cm}$ of small bowel was capable of differentiating between different instillates even after selective extragastric vagotomy, in which the duodenum was vagally denervated and, therefore, duodenal braking receptors function independently of vagal innervation.

It is well established that meals of different composition empty from the stomach at different rates and that this is due to regulation by receptors in the duodenum (Hunt, 1957; Hunt and Knox, 1968a). Differences of opinion exist as to the effects of vagotomy and drainage on the rate of gastric emptying; some workers report that the rate of gastric emptying is increased (Goodall, 1966; George, 1968; Aylett, Wastell, and Wise, 1969; McKelvey, 1970) but others find that it is delayed (Isaac, Ottoman, and Weinberg, 1950; Dragstedt and Woodward, 1951; Buckler, 1967; Tinker, Kocak, Jones, Glass, and Cox, 1970).

In this study we have tried to identify the site of the braking receptors and also to determine the role of the vagus in the regulation of gastric emptying when the pylorus is intact.

\section{Materials and Methods}

Two different experimental models were prepared.

1 Gastric and duodenal fistulae were produced by inserting two Gregory cannulae, one into the stomach and one into the duodenum (fig 1).

2 In another group of animals the duodenum was divided immediately beyond the intact pylorus which was then implanted end to side $50 \mathrm{~cm}$ further down the small bowel. The duodenal stump was closed. At a second operation two cannulae-one into the stomach and one into the duodenumReceived for publication 4 March 1975.

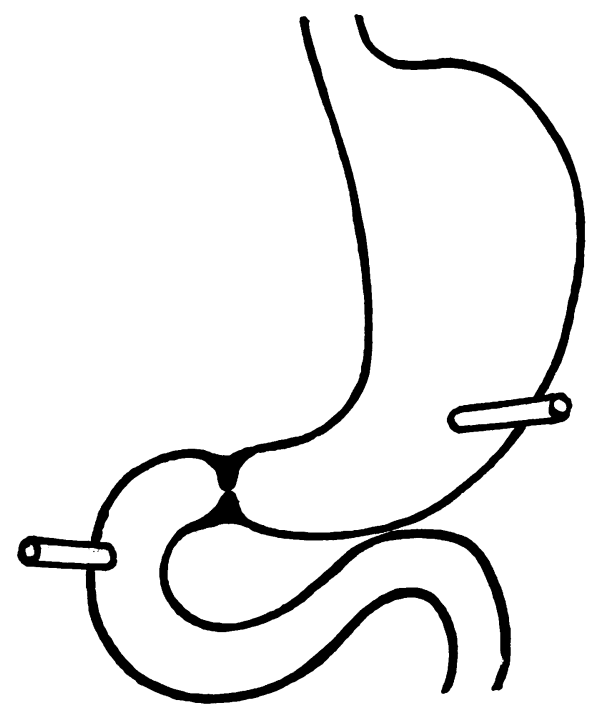

Fig 1 Model 1: Cannulae in the stomach and duodenum.

were inserted in order to produce gastric and duodenal fistulae (fig 2).

Five dogs belonging to model 1 underwent truncal vagotomy, ie, both right and left trunks of the vagus were divided transthoracically. Two dogs belonging to model 2 underwent extragastric selective vagotomy: hepatic and coeliac branches were divided but all other gastric branches, including the nerves of Latarjet, were preserved (fig 3). 


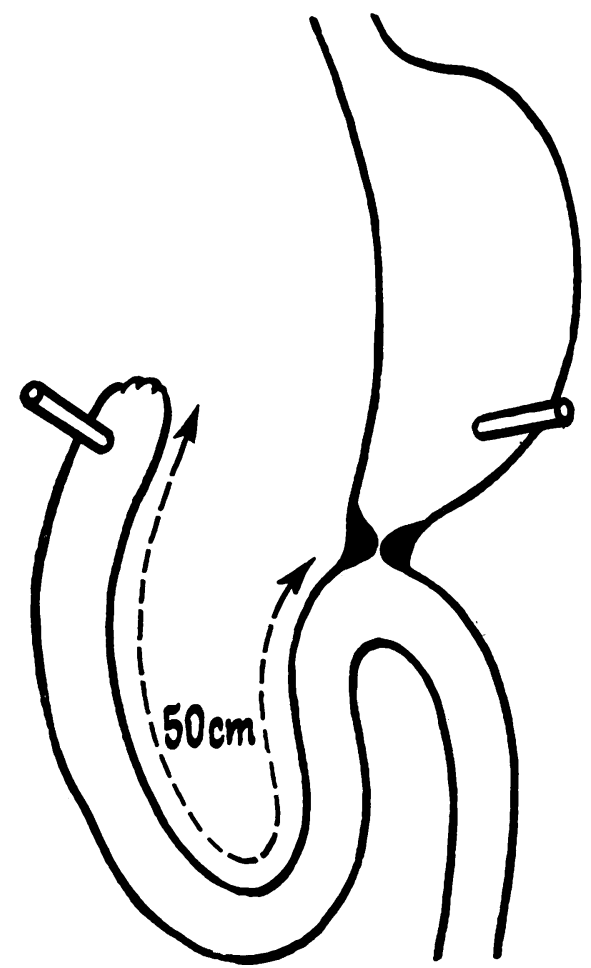

Fig 2 Model 2: Bypass experimental model in which the intact pylorus is implanted $50 \mathrm{~cm}$ down the small intestine.

The gastric fistula facilitated the carrying out of measurements of the rate of gastric emptying. The duodenal fistula was used to introduce different substances into the duodenum and proximal small bowel during the study, eg, deionized water, $250 \mathrm{mM}$ hydrochloric acid, $10 \%$ dextrose, and $5 \%$ fat. The double-sampling dye dilution technique of George (1968) was used throughout to measure the rate of gastric emptying. In the case of the meal containing
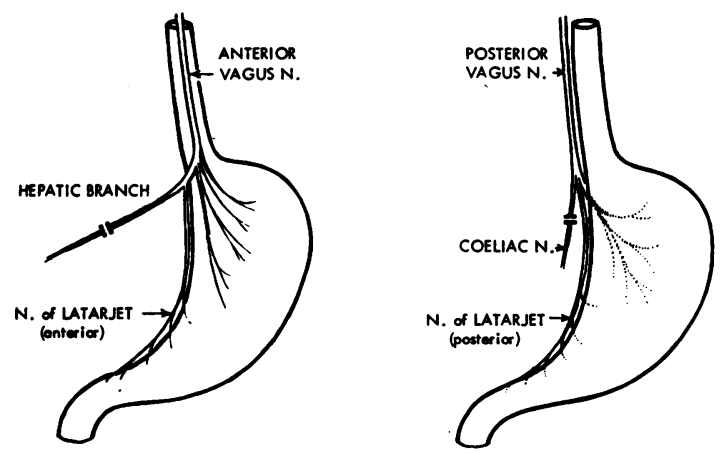

Fig 3 Diagrammatic representation of selective extragastric vagotomy. fat, a special procedure was adopted before optical density was read. It was ensured that specimens were very thoroughly mixed by means of vigorous shaking immediately before removing $4 \mathrm{ml}$ to be made up with $10 \mathrm{ml}$ buffer and distilled water to $100 \mathrm{ml}$. The fat was extracted from this final solution by mixing equal volumes of the solution and diethyl ether. This mixture was very thoroughly shaken, allowed to sit at $4^{\circ} \mathrm{C}$ for 30 minutes, then it was centrifuged at $4^{\circ} \mathrm{C}$. The ether layer and the meniscus between the ether and aqueous layers were removed and the optical density of the residue was read. Calculations were carried out in the usual manner with these results.

Emptying studies were carried out between six and 10 weeks after gastric and duodenal fistulae had been prepared.

All the studies were performed on healthy, conscious dogs. The dogs were kept fasting for about 24 hours before any emptying study was carried out. During the tests, dogs were placed in a Pavlov stand on an elevated table. These dogs had been trained for some days previously to stand in the frame before actual emptying tests were carried out. The cap of the gastric cannula was removed and the stomach allowed to drain on its own. A rubber teat with a small hole at its centre for the passage of the Levin

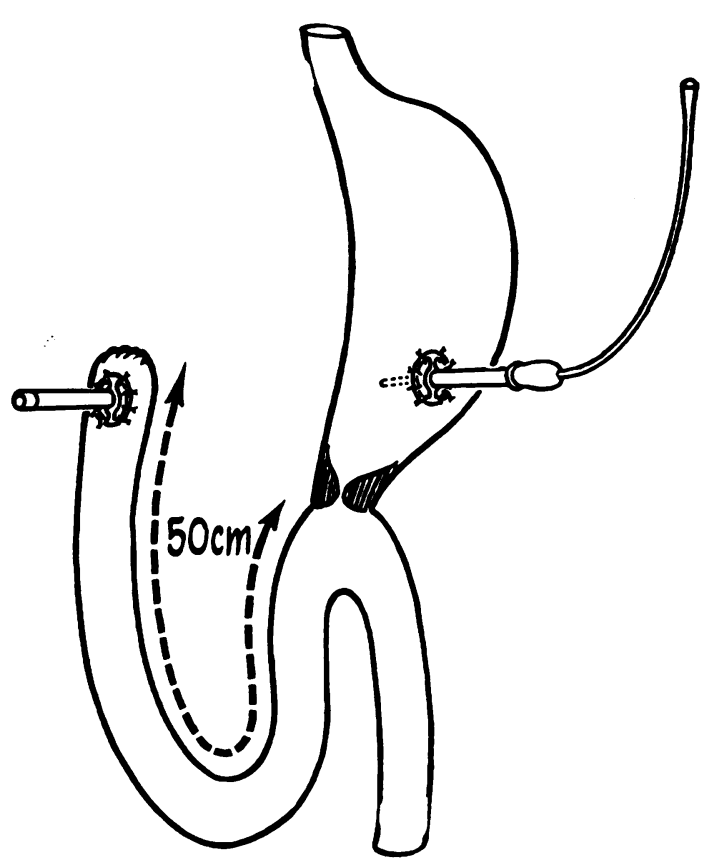

Fig 4 A Levin tube in situ, introduced via a rubber teat and gastric cannula. 
tube was placed at the open end of the cannula to prevent fluid leaking from the stomach (fig 4). A Levin tube size 14 was then introduced into the stomach through the gastric cannula, making sure that just the tip of the tube was lying in the stomach. Another Levin tube was introduced in a similar fashion through the duodenal cannula.

The stomach was washed out with $200 \mathrm{ml}$ of deionized water. It was then ensured that the stomach was emptied as completely as possible by means of careful aspiration with a syringe, moving the tube around the stomach. At the end of this operation the Levin tube and the rubber teat were removed and the stomach was allowed to drain on its own, the cannula being at the most dependent part of the stomach and the dog kept in the erect position.

\section{Results}

In one dog with an intact gastroduodenal junction five emptying studies using $600 \mathrm{ml}$ of water showed the high degree of reproducibility of the test (table I).

\begin{tabular}{lllll}
\hline \multicolumn{2}{l}{ Rate of Emptying (min) } \\
\hline Day 1 & Day 2 & Day 3 & Day 4 & Day 5 \\
\hline 40 & 37 & 41 & 34 & 40 \\
\hline
\end{tabular}

Table I Rate of emptying of water from the stomach ${ }^{1}$

${ }^{1}$ Daily variation in a single dog

In seven dogs with an intact gastroduodenal junction emptying studies were carried out using $600 \mathrm{ml}$ of fluids. It was shown that the rate of emptying of different instillates varied greatly. The mean emptying times in minutes were as follows: deionized water 44 , hydrochloric acid 85 , dextrose 126 , and fat 144 . There were highly significant differences in the rates of emptying between different pairs of instillates in the intact stomach. Detailed results are shown in table II.

\begin{tabular}{|c|c|c|c|c|}
\hline \multirow[t]{2}{*}{ Fluids in Stomach } & \multicolumn{2}{|c|}{ Before Vagotomy } & \multicolumn{2}{|c|}{ After Vagotomy } \\
\hline & $\begin{array}{l}\text { Number of } \\
\text { Studies }\end{array}$ & $\begin{array}{l}\text { Mean Time } \\
(\min ) \\
\pm S E M\end{array}$ & $\begin{array}{l}\text { Number of } \\
\text { Studies }\end{array}$ & $\begin{array}{l}\text { Mean Time } \\
(\min ) \\
\pm S E M\end{array}$ \\
\hline $\begin{array}{l}\text { Water } \\
250 \mathrm{mM} \mathrm{HCl} \\
10 \% \text { dextrose } \\
5 \% \text { fat }\end{array}$ & $\begin{array}{r}26 \\
8 \\
18 \\
15\end{array}$ & $\begin{array}{r}44( \pm 1 \cdot 78) \\
85( \pm 4 \cdot 35) \\
126( \pm 3 \cdot 18) \\
144( \pm 5 \cdot 93)\end{array}$ & $\begin{array}{l}30 \\
22 \\
23 \\
20\end{array}$ & $\begin{array}{r}85( \pm 3 \cdot 57) \\
126( \pm 3 \cdot 67) \\
160( \pm 6 \cdot 23) \\
216( \pm 2.89)\end{array}$ \\
\hline
\end{tabular}

Table II Emptying time before and after truncal vagotomy
Truncal vagotomy was performed in five dogs belonging to model 1; six weeks after vagotomy emptying was then studied using the same instillates. During insulin hypoglycaemia no animal had an acid output of more than 20 -equiv/ 1 or 10 m-equiv if there was no basal acidity, ie, all tests were negative according to Hollander's criteria.

The results of emptying tests are shown in table II and figure 5. It can be seen that the emptying time was significantly altered by interruption of the vagi. After truncal vagotomy the emptying time for each substance became significantly longer, yet the proportional differences between the effects of different substances were maintained.

In eight dogs belonging to model 2 , ie, with the pylorus implanted into the small bowel, gastric emptying studies were carried out putting $500 \mathrm{ml}$ of different substances into the stomach with $100 \mathrm{ml}$ of deionized water introduced through the duodenal cannula (fig 6). With water in the duodenum the

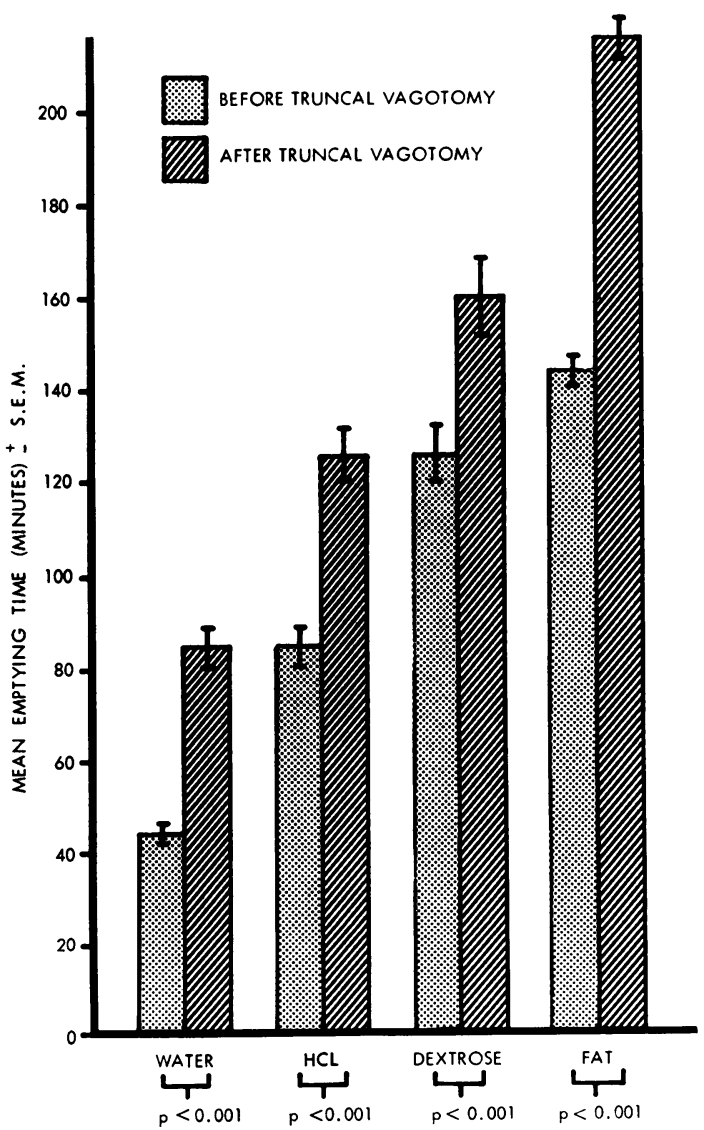

Fig 5 Emptying time before and after truncal vagotomy. 


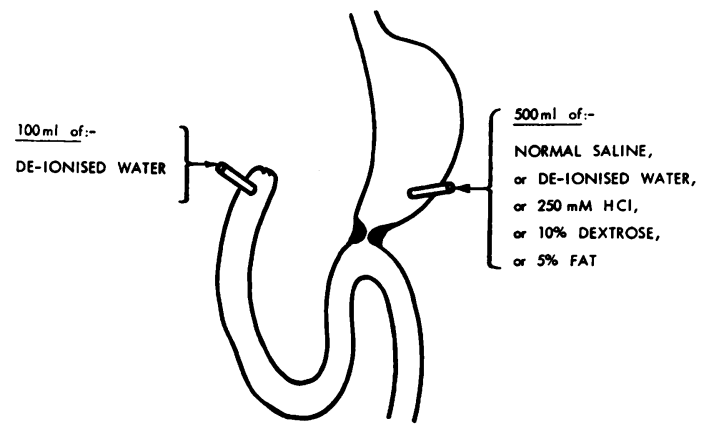

Fig 6 Determination of the emptying time of various agents from the stomach; $100 \mathrm{ml}$ of water only in the proximal small bowel.

different types of instillates all emptied from the stomach at similar rates: for example, water took 54 minutes and dextrose 53 minutes (table III).

\begin{tabular}{lllll}
\hline $\begin{array}{l}\text { Fluid in } \\
\text { Stomach }\end{array}$ & $\begin{array}{l}\text { Agent in } \\
\text { Small Bowel }\end{array}$ & $\begin{array}{l}\text { No. of } \\
\text { Studies }\end{array}$ & $\begin{array}{l}\text { Mean Time } \\
\text { (minutes) }\end{array}$ & SEM \\
\hline Normal saline & Water & 5 & 54 & 3.27 \\
Water & Water & 12 & 54 & $1 \cdot 86$ \\
$250 \mathrm{mM} \mathrm{HCl}$ & Water & 12 & 53 & 2.33 \\
$10 \%$ dextrose & Water & 12 & 53 & 2.57 \\
$5 \%$ fat & Water & 11 & 54 & 1.48 \\
\hline
\end{tabular}

Table III Emptying time in a bypass model

Further studies were carried out in four dogs belonging to model 2 . Five hundred $\mathrm{ml}$ of water was put into the stomach and at the same time $100 \mathrm{ml}$ of different instillates, ie, water, $250 \mathrm{mM}$ hydrochloric acid, $10 \%$ dextrose, or $5 \%$ fat solution were introduced on different days through the duodenal

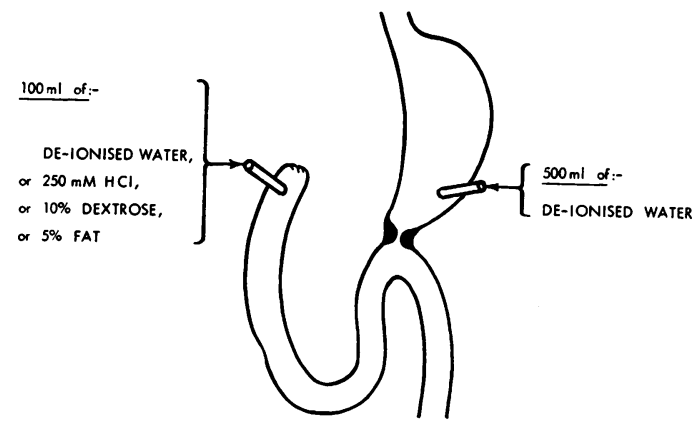

Fig 7 Determination of the role of different agents in the upper small intestine on the rate of emptying of water from the stomach. cannula (fig 7). In these dogs the water emptied from the stomach at different rates depending on the nature of the substance introduced through the duodenal cannula. When water was introduced into the small bowel, the water emptied in 54 minutes, but when $250 \mathrm{mM} \mathrm{HCl}$ or $10 \%$ dextrose or $5 \%$ fat was introduced through the duodenal cannula the mean emptying time became 80, 137, and 160 minutes respectively (table IV).

\begin{tabular}{lllll}
\hline $\begin{array}{l}\text { Fluid in } \\
\text { Stomach }\end{array}$ & $\begin{array}{l}\text { Agents in } \\
\text { Small Bowel }\end{array}$ & $\begin{array}{l}\text { No. of } \\
\text { Studies }\end{array}$ & $\begin{array}{l}\text { Mean Time } \\
\text { (minutes) }\end{array}$ & SEM \\
\hline Water & Water & 12 & 54 & $1 \cdot 86$ \\
Water & $250 \mathrm{mM} \mathrm{HCl}$ & 10 & 80 & $4 \cdot 15$ \\
Water & $10 \%$ dextrose & 13 & 137 & $4 \cdot 85$ \\
Water & $5 \%$ fat & 11 & 160 & $4 \cdot 84$ \\
\hline
\end{tabular}

Table IV Emptying time in a bypass model ${ }^{1}$

${ }^{1}$ Different agents in proximal small bowel ${ }^{2}$ Data as in table III

In two dogs belonging to model 2, selective extragastric vagotomy (division of hepatic and coeliac vagal branches) was performed and six weeks later emptying studies were carried out using water, $10 \%$ dextrose, and $5 \%$ fat. When $500 \mathrm{ml}$ of each of these substances was introduced on different days into the stomach and $100 \mathrm{ml}$ of deionized water was put into the duodenum, the rate of emptying of each instillate from the stomach was similar (table V).

\begin{tabular}{lllll}
\hline $\begin{array}{l}\text { Fluids in } \\
\text { Stomach }\end{array}$ & $\begin{array}{l}\text { Agents in } \\
\text { Small Bowel }\end{array}$ & $\begin{array}{l}\text { No. of } \\
\text { Studies }\end{array}$ & $\begin{array}{l}\text { Mean Time } \\
\text { (minutes) }\end{array}$ & SEM \\
\hline Water & Water & 10 & 51 & 2.43 \\
$10 \%$ dextrose & Water & 7 & 53 & $3 \cdot 21$ \\
$5 \%$ fat & Water & 7 & 52 & 3.34 \\
\hline
\end{tabular}

Table V Emptying time following selective extragastric vagotomy in a bypass model

\section{Discussion}

As one would expect that the passage of the Levin tube into the stomach through the mouth of healthy conscious dogs would disturb the physiological state of the animals, it was considered preferable to introduce the Levin tube into the stomach through a gastric cannula. Knowing the length of the cannula it was possible to introduce the Levin tube so that just the tip lay in the stomach. Radiological screening was not necessary in order to find out if 
the tube was lying in the proper place or if the tube was curled up inside the stomach.

The double-sampling dye dilution technique of George (1968) was found to be satisfactory though a modification was needed in cases of meals containing fat. Fluid meals empty in an exponential pattern. The main disadvantage of the test is that it is only applicable to fluid meals, and it can be argued that the evacuation of fluid from the stomach does not reflect how the stomach deals with a normal mixed meal. Using a mixed meal, Griffith, Owen, Kirkman, and Shields (1966) demonstrated an exponential pattern.

Hunt and Spurrell (1951) have shown that there is very little daily variation in the emptying rates of an individual stomach and the present study has confirmed this. This emptying pattern was found to be exponential in the intact dogs corresponding with the findings of Hunt and Spurrell (1951). On the otherhand, Tamarit Torres, EnríquezdeSalmanca,and Castro-Rial Canosa (1954)found a hyperbolic relationship between the volume of meal remaining in the stomach and time. In the present studies, different substances were used at different concentrations and it was found that normal saline emptied fastest whereas $5 \%$ fat solution took longest to empty, confirming previous work which showed that the rate of emptying varies according to the nature of the meal (Hunt, 1957, 1960; Hunt and Knox, 1968b).

Though the function of the pylorus in model 2 may perhaps have been temporarily interfered with due to the operative procedure its nerve supply and vascular supply were preserved very carefully. The anastomosis was carried out in one layer in order not to cause narrowing of the lumen. Functionally the pylorus behaved normally as shown from the figures in table IV, when water instilled into the stomach emptied at different rates depending on the nature of the instillate in the proximal small bowel. It would appear that the pylorus in this animal experimental model was in no way incontinent. Our studies seem to have identified the proximal $50 \mathrm{~cm}$ of the small bowel as the main site for receptors controlling gastric emptying. If there was a signi-

\begin{tabular}{|c|c|c|c|c|}
\hline $\begin{array}{l}\text { Fluid in } \\
\text { Stomach }\end{array}$ & $\begin{array}{l}\text { Agents in } \\
\text { Small Bowel }\end{array}$ & $\begin{array}{l}\text { No. of } \\
\text { Studies }\end{array}$ & $\begin{array}{l}\text { Mean Time } \\
\text { (minutes) }\end{array}$ & $S E M$ \\
\hline $\begin{array}{l}\text { Water }{ }^{2} \\
\text { Water } \\
\text { Water }\end{array}$ & $\begin{array}{l}\text { Water } \\
10 \% \text { Dextrose } \\
5 \% \text { Fat }\end{array}$ & $\begin{array}{r}10 \\
9 \\
9\end{array}$ & $\begin{array}{r}51 \\
136 \\
163\end{array}$ & $\begin{array}{l}2 \cdot 43 \\
3 \cdot 34 \\
4 \cdot 79\end{array}$ \\
\hline
\end{tabular}

Table VI Emptying time following selective extragastric vagotomy in new bypass model ${ }^{1}$

${ }^{1}$ Different agents in proximal small bowel ${ }^{2}$ Data as in table V ficant number of receptors more than $50 \mathrm{~cm}$ distal to the pylorus, then different instillations into the stomach might be expected to empty at different rates. That this was not the case might be due to the very much slower rate of passage of fluid from the stomach into the jejunum compared with the rate of infusion into the duodenum. This is probably not the explanation, however, as our findings in model 1 dogs with no bypass and an intact pylorus show that different instillations into the stomach do empty at different rates.

Emptying time following vagotomy and drainage is disputed (Buckler, 1967). Tinker et al (1970), who used meals of a more solid nature, showed delayed emptying after vagotomy and drainage. In our series the emptying time for each instillate following vagotomy was significantly prolonged. The ability to differentiate between different instillates was maintained.

Other investigators who have used fluid meals have reported an overall increase in the rate of gastric emptying (Goodall, 1966; George, 1968; Aylett et al, 1969; McKelvey, 1970) which is in conflict with our findings. Apart from species differences the main point of variance is the absence of pyloroplasty or any drainage procedure in our animals. McKelvey (1970) thought that abnormal emptying following vagotomy and drainage was due to loss of duodenal regulation of emptying but could not say whether this was due to the vagotomy or the drainage procedure. It may be that the abnormality of gastric emptying is mainly due to the drainage operation. The superior results following highly selective vagotomy without drainage are probably due to preservation of the pylorus rather than preservation of the vagal supply to the distal part of the stomach and small bowel.

Hunt and his colleagues (1966) have shown that there are duodenal receptors involved in the control of gastric emptying but they have not demonstrated precisely how far down the gut these receptors extend. From our studies on dogs it would appear that most, if not all, the braking receptors lie in the proximal $50 \mathrm{~cm}$ of the small intestine. It seems unlikely that there are a significant number of such receptors further distally.

It is concluded that vagal innervation of the stomach is important in the mechanism of gastric emptying but that duodenal innervation is not essential for the function of the braking receptors which appear to work through a hormonal mechanism. It should be stressed that these conclusions relate to canine experiments and are not necessarily applicable to human physiology.

We wish to record our thanks to the Royal Victoria 
Hospital Group Research Sub-Committee for a grant to one of us (M.S.) from their endowment funds which has made it possible to undertake this work. Professor A. D. Roy has kindly provided facilities for the study in the Department of Surgery, Queen's University, Belfast. We also wish to thank Mr H. O. Nevin, Mr J. White, and Sister E. Crawford for technical assistance, and Mrs S. Leonard and Mrs J. Walker for secretarial help.

\section{References}

Aylett, P., Wastell, C., and Wise, I. (1969). Gastric secretion and emptying before and after vagotomy and pyloroplasty, with and without continuous infusion of peptavlon pentagastrin. Amer. J. dig. Dis., 14, 245-252.

Buckler, K. G. (1967). Effects of gastric surgery upon gastric emptying in cases of peptic ulceration. Gut, 8, 137-147.

Dragstedt, L. R., and Woodward, E. R. (1951). Appraisal of va zotomy for peptic ulcer after seven years. J. Amer. med. Ass., 145, 795.

George, J. D. (1968). New clinical method for measuring the rate of gastric emptying: The double sampling test meal. Gut, 9, 237-242.

Griffith, G. H., Owen, G. M., Kirkman, S., and Shields, R. (1966). Measurement of rate of gastric emptying using chromium- ${ }^{51}$.
Lancet, 1, 1244-1245.

Goodall, P.(1966). The effect of vagotomy and a drainage procedure on the rate of gastric emptying. Brit. J. Surg., 53, 995.

Hunt, J. N., and Knox, M. T. (1968a). Regulation of gastric emptying. In Handbook of Physiology, Sect. 6, edited by C. F. Code, Vol. IV, pp. 1917-1935. American Physiological Society Washington, D.C.

Hunt, J. N., and Knox, M. T. (1968b). A relation between the chain length of fatty acids and the slowing of gastric emptying. $J$. Physiol. (Lond.), 194, 327-336.

Hunt, J. N., and Spurrell, W. R. (1951). Pattern of emptying of human stomach. J. Physiol. (Lond.), 113, 157-168.

Hunt, J. N. (1957). Influence of hydrochloric acid on gastric secretion and emptying in patients with duodenal ulcer. Brit. med. J., 1, 681-684.

Hunt, J. N. (1960). The site of receptors slowing gastric emptying in response to starch in test meals. J. Physiol. (Lond.), 154, 270-276.

Isaac, F., Ottoman, R. E., and Weinberg, J. A. (1950). Roentgen studies of the upper gastro-intestinal tract in vagotomy, Amer. J. Roentgenol., 63, 66.

McKelvey, S. T. D. (1970). Gastric incontinence and post-vagotomy diarrhoea. Brit. J. Surg., 57, 741-747.

Tamarit Torres, J., Enríquez de Salamanca, F., Jr., and CastroRial Canosa, M. (1954). El ritmo de apertura pilorica en el ulcus gastroduodenal. Arch. Med. exp. (Madr.), 12, 99-118.

Tinker, J., Kocak, N., Jones, T., Glass, H. I., and Cox, A. G. (1970). Supersensitivity and gastric emptying after vagotomy. Gut, 11, 502-505. 